\title{
Community perception, adaptation and resilience to extreme weather in the Yucatan Peninsula, Mexico
}

\author{
Sarah E. Metcalfe ${ }^{1}$ (D) B Birgit Schmook ${ }^{2}$ (D) - Doreen S. Boyd ${ }^{1}$ (D) - Betsabe De la Barreda-Bautista ${ }^{1}$ (D) \\ Georgina E. Endfield ${ }^{4}$ (D) Sofia Mardero ${ }^{3}$ - Maria Manzón Che ${ }^{2}$. Roger Medina González ${ }^{5}$. \\ Maria Teresa Munguia Gil ${ }^{6} \cdot$ Santana Navarro Olmedo ${ }^{2}$ (D) $\cdot$ Alejandra Perea $^{6}$
}

Received: 29 May 2019 / Accepted: 16 January 2020 / Published online: 17 February 2020

(C) The Author(s) 2020

\begin{abstract}
Perceptions of climate change, the impacts of and responses to climatic variability and extreme weather are explored in three communities in the Yucatan Peninsula, Mexico, in relation to livelihood resilience. These communities provide examples of the most common livelihood strategies across the region: small-scale fisheries (San Felipe) and semi-subsistence small-holder farming (Tzucacab and Calakmul). Although the perception that annual rainfall is reducing is not supported by instrumental records, changes in the timing of vital summer rainfall and an intensification of the mid-summer drought (canicula) are confirmed. The impact of both droughts and hurricanes on livelihoods and crop yields was reported across all communities, although the severity varied. Changes in traditional milpa cultivation were seen to be driven by less reliable rainfall but also by changes in Mexico's agricultural and wider economic policies. Diversification was a common adaptation response across all communities and respondents, resulting in profound changes in livelihood strategies. Government attempts to reduce vulnerability were found to lack continuity, be hard to access and too orientated toward commercial scale producers. Population growth, higher temperatures and reduced summer rainfall will increase the pressures on communities reliant on small-scale farming and fishing, and a more nuanced understanding of both impacts and adaptations is required for improved livelihood resilience. Greater recognition of such local-scale adaptation strategies should underpin the developing Mexican National Adaptation Policy and provide a template for approaches internationally as adaptation becomes an increasingly important part of the global strategy to cope with climate change.
\end{abstract}

Keywords Drought $\cdot$ Hurricane $\cdot$ Weather lore $\cdot$ Diversification

Communicated by Jamie Pittock

Electronic supplementary material The online version of this article (https://doi.org/10.1007/s10113-020-01586-w) contains supplementary material, which is available to authorized users.

Sarah E. Metcalfe

sarah.metcalfe@nottingham.ac.uk

Birgit Schmook

bschmook@ecosur.mx

Doreen S. Boyd

doreen.boyd@nottingham.ac.uk

Betsabe De la Barreda-Bautista

betsabe.delabarreda@nottingham.ac.uk

Georgina E. Endfield

Georgina.endfield@liverpool.ac.uk

Sofia Mardero

sm465@st-andrews.ac.uk
Maria Manzón Che

manzonmari@gmail.com

Roger Medina González

rmedina@uady.mx

Maria Teresa Munguia Gil

Teresa.munguia@correo.uady.mx

Santana Navarro Olmedo

naos.enah@gmail.com

Alejandra Perea

Alejandra.pereablaz@gmail.com

Extended author information available on the last page of the article 


\section{Introduction}

Although climate change is a global problem and key policy initiatives around mitigation tend to be taken at a national level, success in avoiding the worst impacts of increasing climatic risks, particularly at a local scale, depends on a genuine integration of the scientific understanding of climate, with that based in the social sciences (Adger 2000; Royal Society 2014; Weaver et al. 2014). As Endfield and Morris (2012) pointed out, the predominantly scientific and global scale of much discussion of climate change "have obscured the culturally specific and spatially and temporally distinctive meanings of climate more generally" (p. 1). Coping effectively with climate change (i.e. adaptation), including the changing frequency and intensity of extreme weather events, means focusing on specific contexts, geographical, cultural and personal (Eakin 2005; Adger et al. 2013; Hackmann et al. 2014; IPCC 2014; Clayton et al. 2015; Williams et al. 2015). This challenge is particularly urgent in less developed economies, where the impacts of climate change and extreme weather are likely to be especially acute, threatening current and future development goals (Cannon and Müller-Mahn 2010; De La Fuente and Olivera Villarroel 2013; Soares et al. 2014), disproportionately affecting the poorest and most vulnerable people (Tanner et al. 2015). It has been suggested that climate change may actually be used as an excuse for development "failures" which limit the effectiveness of disaster risk reduction (Gaillard 2010).

Debates around climate change and development often revolve around discussions of the concepts of vulnerability, adaptation and resilience, which themselves emerge from the differences between scientific or technological approaches and those which take more account of power relations in socio-economic processes (Eriksen et al. 2015). The IPCC defines adaptation as "The process of adjustment to actual or expected climate and its effects. In human systems, adaptation seeks to moderate harm or exploit beneficial opportunities. In natural systems, human intervention may facilitate adjustment to expected climate and its effects" (2014, p. 838). Since 2007, this idea has been one of four "building blocks" needed to address climate change (Dodman and Mitlin 2013). The IPCC recognise two forms of adaptation: incremental (maintaining the basic characteristics of the system under threat) and transformational (changing the status quo). Eriksen et al. (2015) emphasise that adaptation is a socio-political process (not just technical/managerial) noting that "adaptation is a profoundly social process that includes informal and formal institutions, learning, diverse local values and negotiation of interests" (p. 526). Adaptation can be explored at many scales, but here, our focus is at the community/individual level.

The adoption in climate change debates of the idea of resilience, originally used in modelling change in ecological systems, has been fiercely debated and critiqued (e.g.
Adger 2000; Cannon and Müller-Mahn 2010; Mitchell and Harris 2012; Brown 2014; Tanner et al. 2015), but the term is now widely used across both the development and climate change literature. Although the basic idea of resilience as the ability of a system to absorb change seems clear, whether this means that the system then returns to its previous state (i.e. maintaining the status quo) or can be a means to challenge that status quo and lead to longer term change has been more hotly debated (Brown 2014; Tanner et al. 2015). This difference reflects that between incremental and transformational adaptation outlined above. The latter, more dynamic interpretation seems more appropriate in the context of climate change and climate change adaptation and is consistent with Mitchell and Harris's (2012) view of resilience as a process, rather than an outcome. Whether adaptation and resilience are part of the same concept has also been debated, with Audefroy (2015) claiming that they are unrelated, while Brown (2014) suggests that adaption is part of resilience. Here, we see the two as linked, as suggested by Brown.

A key development challenge is that the poorest, most vulnerable societies are those least able to address climate change threats. Moreover, the threat posed by "double exposure" to the impacts of both climate (and climate change) and political and economic change (specifically globalisation and associated liberalisation) is also important in determining vulnerability and resilience (O'Brien and Leichenko 2000) and is often most acute in the Global South. Growing scientific and political concern about this differential social vulnerability means that countries in the Global South should be a priority for climate change adaptation policies (Doulton and Brown 2009). Yet there are obstacles to developing such policy because of the following: (1) limited availability of meteorological data and poor "climate literacy" in these areas; and (2) many in the Global South are simply not in a position to engage with the climate change crisis because of extreme poverty (Duxfield 2007).

This paper is based at the community level in the Yucatan Peninsula, Mexico, with a focus on how climate change (and extreme weather) is perceived and understood and the evidence within communities of local adaptation (and, indirectly, adaptive capacity). We draw quite heavily on Tanner et al.'s (2015) case for a focus on livelihood resilience as a way of bridging some traditional disciplinary and policy boundaries and the idea that "we need to understand the consequences of environmental change for the everyday lives of people, their interpretations of such change and their visions for possible and effective response options" (Hackmann et al. 2014 p. 655). We discuss some aspects of climate change and responses at federal level in Mexico, before introducing our study region and study sites. Following a description of our "Methods", the "Results" section is presented in relation to perceptions, impacts, adaptations and resilience. The 
"Discussion and conclusions" section reflects on our key findings and places these in a wider, international context.

\section{Mexico: national context}

Mexico is highly vulnerable to climate change (Christensen et al. 2013), with both increasing temperatures and decreasing rainfall in the summer wet season, particularly in the south of the country and affecting the Yucatan Peninsula (YP) (Colorado-Ruiz et al. 2018). The growing economic cost of extreme hydrometeorological events has been identified by the Programa Especial de Cambio Climático (PECC) (Special Climate Change Programme) (Diaro Oficial de la Federación 2014), increasing more than $30 \times$ between 1980 1999 and 2000-2012 to reach Mx\$21,950 million (around US\$ 1.1 billion), but they note that the severity of impacts of these events is highly dependent on the socio-economic, political and cultural contexts of those affected, with indigenous peoples being amongst the most vulnerable. This echoes the nature of the debates outlined above.

The institutional framework for climate change in Mexico is based on the Comisión Inter-Secretarial de Cambio Climático (CICC) (Inter Departmental Climate Change Commission) established in 2005, which instituted the Sistema Nacional de Cambio Climático (National Climate Change System) and the Fondo para el Cambio Climático (Fund for Climate Change). At Federal level government, action is implemented through the PECC 2014-2018 (Diario Oficial de la Federación 2014) and the Estrategia Nacional de Cambio Climático (ENCC) (National Climate Change Strategy) established in 2007 which focuses on ways of reducing vulnerability in relation to society, infrastructure and ecosystems. PECC is also linked to the Programa Nacional de Desarrollo (National Development Programme) 2013-2018. These structures have equivalents at state level, which are discussed below. There have been studies of vulnerability to climate change at municipal level (Borja-Vega and de la Fuente 2013) and of the possible impact of climate change on poverty levels (de la Fuente and Olivera Villaroel 2013). Borja-Vega and de la Fuente (2013) found that all the states in the YP have above average risk compared with Mexico as a whole, particularly Campeche (CAM) and Quintana Roo (QR). Projections to 2045 indicate persistent high vulnerability across the peninsula, with Yucatan (YUC) becoming relatively more vulnerable than it is today. It has been noted, however, that while mitigation strategies are well developed in Mexico, this is not true of adaptation strategies (Sanchez Triana et al. 2016).

There are a number of federal funding schemes to help to reduce the impacts of meteorological and other types of disasters (see Online Resource 1 for details). These include FONDEN catastrophe bonds and the CADENA index-based weather insurance scheme. Siniestro is another disaster insurance fund, specifically targeting agriculture. The potential of such schemes for reducing the vulnerability of farming, especially subsistence farming communities, is particularly important in the context of the increasing liberalisation of Mexican agriculture over the last 30 years and especially after the creation of the North American Free Trade Area (NAFTA) in 1994 (Eakin 2005). Beginning in the 1980s, the Mexican government modified economic policies towards greater trade liberalisation with structural reforms (Eakin 2005; Schmook et al. 2013). As a consequence, direct support for small-scale agriculture declined, including the withdrawal of most price support for staples such as maize and beans (Appendini et al. 2003; Eakin, 2005; Echánove and Steffen 2003; Gravel 2007; Mardero et al. 2015).

There are, however, still a large number of support and compensation schemes which operate across the agricultural sector (farming and fishing), some specifically helping it deal with the impacts of liberalisation (see Online Resource 2 for details). These include PROCAMPO, PIMAF (now merged) and PROGAN. Progresa (now Prospera), Mexico's main CCT (Conditional Cash Transfer programme) for poverty alleviation, was introduced in 1997. It is a key part of Mexico's antipoverty strategy, reaching about $25 \%$ of Mexico's citizens (Schmook et al. 2019). In the smallholder sector, it has served as a safety net by providing cash that families use to purchase food (Hoddinott et al. 2000; Skoufias 2005) and has been used to finance crop production (Radel et al. 2017). In practice, Prospera has subsidised agriculture, even though it was not originally designed to do this. For fishing communities, there are two main support schemes: PET and \$Peso $\times$ \$Peso. These and other schemes contribute to the socio-economic context which may help to determine vulnerability and resilience in the face of climate change in the context of the general retreat of the state from the agricultural sector described above and the growth of industrial scale fisheries.

\section{Study region}

The Yucatan Peninsula includes SE Mexico, Belize and part of northern Guatemala (Fig. 1). It is marked by its largely flat topography (mainly below $150 \mathrm{~m}$ asl) and limestone geology, which leads to a scarcity of surface drainage and a high reliance on groundwater or water storage to maintain water supplies between rainy seasons. The southern part of the Peninsula has a higher relief (up to $400 \mathrm{~m}$ asl), which can result in rather different responses to extreme weather events than in the lowlands. The Mexican part of the YP includes three states: Quintana Roo (QR), Yucatan (YUC) and Campeche (CAM), with a combined population of around 4.1 million, most in YUC. Across the peninsula, a high proportion of the population $(20.4 \%)$ are indigenous, Maya 


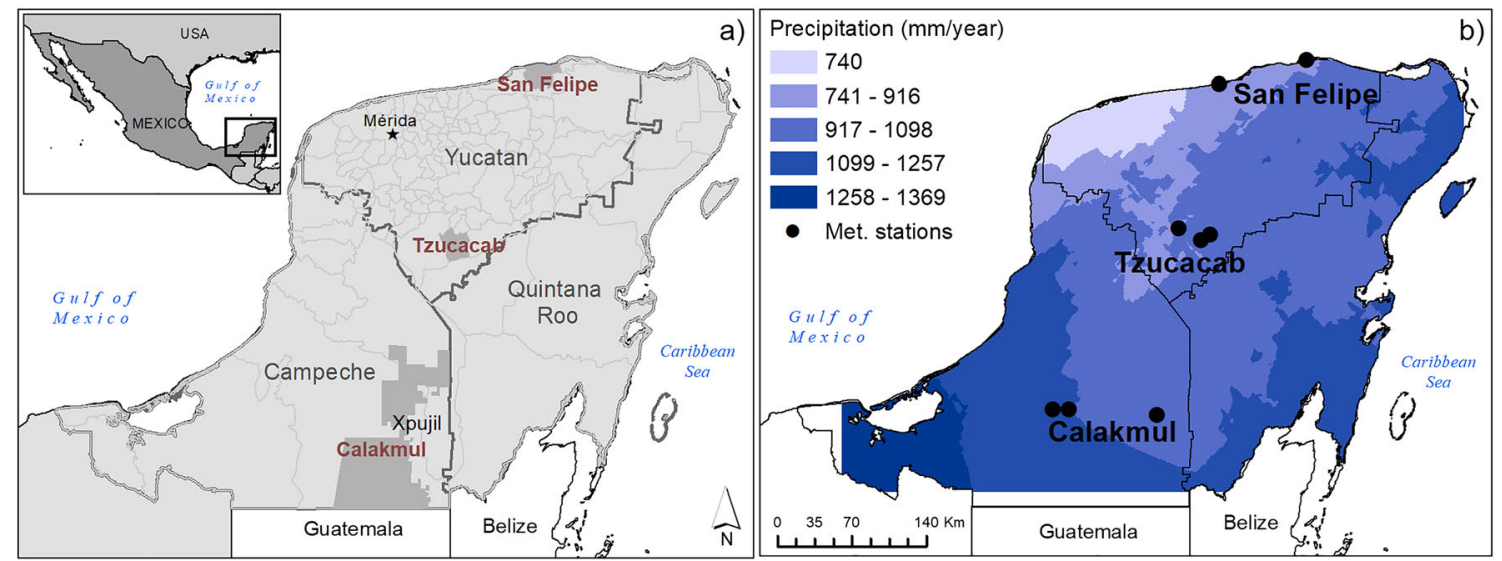

Fig. 1 Location of the three study areas (San Felipe, Tzucacab and Calakmul) in relation to state boundaries (left), annual precipitation amount and location of the closest meteorological stations (right)

speakers, about 58\% in the state of Yucatan (Gobierno del Estado de Yucatán 2013a).

The Mexican YP receives relatively low annual rainfall ( 600 to $1600 \mathrm{~mm}$ ), with a clear gradient from the drier north to the wetter south (Fig. 1). It experiences high temperatures and frequent tropical storms and hurricanes (lying close to the Main Development Region for Atlantic hurricanes) and other extreme weather events, like droughts. The peninsula has a long history of weather- and climate-related disasters. Over the last century, 86 hurricanes have hit QR, 38 YUC and 37 CAM (Gobierno del Estado de Yucatán, 2014a). When category III hurricane Isidore crossed the peninsula in 2002, rural Maya communities were badly affected, losing most of their means of livelihood as well as their homes (UADY 2003). Damage along $>80 \%$ of YUC's coastline caused the loss of more than 1000 fishing vessels, valued at \$3.9 million (Gobierno del Estado de Yucatán, 2014c, Annex 7). The financial impact of hurricane Wilma (2005, category V) on QR's coast was estimated at US $\$ 1.75$ billion, while category V hurricane Dean (2007) crossed the southern part of the peninsula, causing extensive damage in Campeche (Navarro-Martínez et al. 2012). García Acosta (2002) has reviewed hurricane occurrence and noted that disasters are the result of an accumulation of vulnerabilities closely related to levels of poverty, inequality, access to land and income.

Droughts are another long-term problem across the peninsula (Mendoza et al. 2007); July 2015 saw drought declared in $87.5 \%$ of the peninsula (Monitor de Sequía en Mexico (Mexico Drought Monitor)). From mid-2016 until June 2017, drought conditions were recorded over much of the peninsula (see below). Debate over the importance of drought extends back to its possible role in the Maya "collapse" around $\mathrm{AD} / \mathrm{CE}$ 900, but even then, it is argued that changing socio-economic and political contexts affected people's ability to adapt, i.e. resilience (Turner II and Sabloff, 2012; Douglas et al. 2015). With evidence for increasing temperatures (2016 and 2017 were the warmest on record nationally for CAM and QR respectively (CONAGUA 2016; Blunden and Arndt, 2017, Blunden and Arndt, 2018)), droughts are likely to become more frequent (Gobierno del Estado de Yucatán, 2014b, Annex 6). An increase in the number of extreme weather events affecting the peninsula has already been noted (Online Resource 3). Orellana et al. (2009) produced a series of regional climate projections for the YP focusing on temperature. Decreasing precipitation and projections of future warming $\left(2-4^{\circ} \mathrm{C}\right)$ and widespread drying are reported in Gobierno del Estado de Yucatán, 2014b and c, Annexes 6 and 7).

State level institutions related to climate change are well developed in all three YP states, although focusing on mitigation. A peninsula-wide Estrategia Regional de Adaptación al Cambio Climático de la Península de Yucatán (Regional Climate Change Strategy for the Yucatan Peninsula) was produced in 2010 and in 2015; a Regional Climate Change Commission (Comisión Regional de Cambio Climático de la Peninsula de Yucatan) was established. Further details for the individual states are given in Online Resource 4, with climate change action plans launched between 2013 and 2015.

The economic bases of the YP states are very different, with QR highly dependent on tourism, CAM on oil, gas and agriculture and YUC on services and tourism (Sánchez Triana et al., 2016). In all cases, however, small scale, rainfed subsistence agriculture by predominantly indigenous farmers remains important, with agricultural production below the national average in most sectors (Gobierno del Estado de Yucatán 2013a; Mardero et al. 2015). Traditional milpa cultivation (shifting cultivation of maize, beans and squashes) remains central to the rural economy and identity in many areas and has been under pressure from a range of changes, including climate change (Mardero et al. 2018). Small-scale fisheries dominate the economies of many coastal settlements, particularly in YUC (Red de Género y Medio Ambiente 2010). Future projections of a continuation in the trend shown in Online Resource 3 increase the need to understand what 
determines systems' and communities' resilience to extreme weather events in this region and how these pressures interact with increasing globalisation and economic liberalisation (Schmook et al. 2013).

Given the likely magnitude of climate change impacts and its vulnerability to this change, this paper focuses on three contrasting communities across the YP. San Felipe (YUC) is typical of small-scale fisheries, while communities around Tzucacab (YUC) and Calakmul (CAM) (Fig. 1) largely represent semi-subsistence smallholder farming. Some further details of each community, including their main sources are external support, are summarised in Online Resource 5. Although gender is widely acknowledged as important in determining vulnerability to climate change (Arora-Jonsson 2011; Soares et al. 2014) and there is significant research on this topic, we do not explore this in detail in this paper. Through these case studies, we explore the impacts of and responses to climatic variability and extreme weather and attempt to identify what is understood by, constitutes and determines resilience, specifically livelihood resilience, at community level. Previous studies in the area, such as those of Perea Blázquez (2011), Soares et al. (2014), Mardero et al. (2015), Schneider and Haller (2017) and Audefroy and Cabrera Sánchez (2017) provide valuable points of reference for our study, but we believe that this is the first exploration of these issues in the YP across multiple climate risks and multiple communities with different livelihood strategies.

\section{Study sites}

\section{San Felipe}

San Felipe is a small fishing port on the north coast of the YP (Fig. 1). It is located in the low-lying coastal plain, in a natural environment of barrier beaches and lagoons (García de Fuentes et al. 2011). The Ria Lagartos Federal Reserve area is $11 \mathrm{~km}$ to the west. It lies in one of the driest parts of the peninsula (annual rainfall 500-600 mm, Online Resource 5) and is regularly in the path of Atlantic hurricanes. Between 2002 and 2007 alone, hurricanes Isidore (2002), Emily (2005) and Dean (2007) all hit the area, giving rise to declarations of disaster. According to the Atlas de Peligros por Fenómenos Naturales (Natural Hazard Atlas) of the State of Yucatan (Gobierno del Estado de Yucatán 2013b), San Felipe is highly susceptible to severe meteorological droughts, as well as flooding caused by torrential rainfall. As noted by Soares and Murillo Licea (2013), San Felipe's population has always faced natural phenomena, which are now more intense and frequent.

According to INEGI and Gobierno del Estado de Yucatán (2017), San Felipe has a population of 1945. It is classified as having a medium level of marginalisation (CONAPO 2016); the San Felipe region has $71.1 \%$ of its population living in poverty $(60.49 \%$ living on less than two minimum salaries (Mx\$88.36 per day in 2018) (Gobierno del Eastado de Yucatán 2013a). Compared with Tzucacab and Calakmul, San Felipe has a high level of provision of piped water (> $98 \%$ ) and indoor sanitation (>99\%) (CONAPO 2016). The main economic activity is fishing, primarily for grouper, lobster, squid, shark and seasonally, for sea cucumber. The highly profitable sea cucumber industry has encouraged both temporary and permanent immigration from other parts of Mexico, provoking conflicts between locals and incomers. In recent years, local fishermen have been purchasing ranches on the outskirts of the town to raise cattle, often using money sent to them by children working in the big coastal resorts of Cancun and Playa del Carmen in QR. The PET and Peso $\times$ Peso support programmes (see above and Online Resource 2) are important for San Felipe, and local tourism also contributes to its economy. In contrast, the cultivation of maize and beans has largely ceased to have any economic importance.

\section{Tzucacab}

Tzucacab is both an ejido (collectively held land, with tenure underwritten by the state) and a town in a forested area in the southern part of Yucatan, close to a ridge known as the Sierra de Ticul (Fig. 1, Online Resource 5). It has a population of 14,784 (INEGI Encuesta Intercensal, 2016), and its climate is subhumid (annual rainfall $800-1000 \mathrm{~mm}$ ). Tzucacab is susceptible to severe meteorological droughts, and highly susceptible to forest fires and floods (Gobierno del Estado de Yucatan 2013b). Tzucacab has a high index of marginalisation, with $66.82 \%$ of the employed population receiving less than two minimum salaries (CONAPO 2016). Nearly $13 \%$ of houses lack indoor sanitation, but more than $98 \%$ of households have piped water.

People in Tzucacab and its wider region depend on cattle ranching and small-scale irrigated agriculture, including milpa and fruit and vegetable growing, with products sold through the market in Oxkutzcab. Irrigation was introduced in the 1960 s as part of a range of state interventions to stimulate agricultural development and gave rise to the mix of traditional production methods and more commercialised production with both irrigation and mechanisation (Rosales and Rejón 1983). Access to irrigation now plays a key role in determining how agriculturalists manage their time. Near Tzucacab, we worked with Rancho Hobonil (currently run by the Universidad Autónoma de Yucatan, UADY) and farmers from several other nearby localities.

\section{Calakmul}

The municipality of Calakmul (CAM) lies in the south of the YP, bordering onto Guatemala (Ibarra-Manríquez et al. 2002) (Fig. 1). The local topography consists of low hills (Meseta 
Baja de Zoh-Laguna) up to a maximum elevation of $390 \mathrm{~m}$ asl. The climate is very similar to Tzucacab, but with a slightly lower average annual temperature and higher annual average precipitation (900-1400 mm) (Vester et al. 2007). Around $94 \%$ of the municipality is forested (Online Resource 5), including the biosphere reserve of Calakmul. There are only a few, seasonal, surface water bodies in the southern part of the biosphere reserve (García Gil et al. 2002). Calakmul is highly susceptible to meteorological droughts and hurricanes (Márdero et al., 2012; Posada Vanegas et al. 2013), Hurricane Dean (2007) being one of the most destructive. The main town of the municipality is Xpujil, the only settlement of any size ( $>2500$ people). The total population of 28,424 (INEGI and Gobierno del Estado de Campeche 2017) is scattered across more than 80 communities. Calakmul is not prosperous; it is classified as the second most marginalised municipality in the whole of Campeche (CONAPO 2016). Martínez Romero (2010) reported that $40 \%$ of the population experienced food shortages, and lack education and skills. At the municipal level, more than $32 \%$ of households lack piped water.

Our work has focused on two ejidos in Calakmul: Nuevo Becal and La Guadalupe (Fig. 1, Online Resource 5), both established after 1970. Nuevo Becal is a forest ejido, with the extraction of timber and gum (chicle) being the main economic activities, with some maize cultivation. La Guadalupe is smaller, with subsistence and commercial agriculture producing maize and beans, and small areas of jalapeño chillies and chihua (a type of squash). Neither ejido has piped water nor drainage/ sewerage systems, so water supply for domestic use relies on small-scale water capture systems (mainly tanks). Water scarcity is a major source of stress to these communities; when households are forced to buy water by the tanker-load, this can cost up to 5 times more than the daily minimum salary (see above) depending on transport distance. Outmigration is an issue, with high reliance on remittances from family members who have moved to Cancun and Playa del Carmen or the USA.

\section{Methods}

Our interdisciplinary research team had previously worked in all three study locations, with long-standing engagements with the communities of San Felipe and Calakmul. We used snowball-sampling techniques (Noy 2008), conducting 57 interviews with smallholders, ranchers and fishermen, four with government officials and four with specialists, who gave us a broader perspective on the impacts of droughts, hurricanes and smallholder resilience strategies (for details, see Online Resource 6). By interviewing 65 knowledgeable individuals, we exceeded the threshold of 6-12 expert respondents considered sufficient to capture the range of cultural information on a given topic (Guest et al. 2006). We also employed participant observation in the communities and accompanied ranchers and farmers to their holdings, when possible. This enabled us to observe the effects of the ongoing drought (see below) first hand, and to discuss adaptation strategies in situ. Four of our team members spent 10-15 days in each of the study sites in early 2017. During fieldwork, we found it necessary to "translate" academic terms like "climate change" into language accessible to our respondents. Frequently, our questions about climate change and its impacts, as initially phrased, caused confusion among farmers, ranchers and fishermen. As a result, the preferred option was to refer to climate change in relation to weather, el tiempo. This outcome was consistent with the ideas expressed by Hulme (2009) and de Vet (2013) that talking about weather is the way to understand climate.

In addition to the in-depth and semi-structured interviews, we organised eight focus groups to talk with people informally and allow participants to learn from each other and thereby experience the research as a more participatory and enriching experience (Hollander 2004). These focus groups, unlike individual interviews, provided collective information about the communities' experiences in the face of hurricanes and droughts, and how and whether people were recovering from their losses. Participants developed a timeline (see Reenberg et al. 2012 for a useful definition), describing their livelihood strategies before and after severe weather events and how these events have transformed their livelihoods.

We organised the information into the following categories: (1) climate perception, weather, seasonality, weather lore and predictions; (2) contextual/lived situation in relation to droughts, hurricanes and temperature change (amongst others); (3) climate/weather effects; (4) forms of resilience; (5) government subsidies and other actions; (6) food security. These categories emerged from an examination of the data (inductively), and data were coded and classified in Dedoose, online qualitative analysis software https://www.dedoose.com/. Although use was made of this software, our approach was primarily qualitative, and our discussion reflects this.

After a preliminary examination of field data, we organised a workshop in Merida, the state capital of Yucatan (Fig. 1), to gather feedback on the initial results of our analysis. Invited participants included academics in the Peninsula researching climate change, government and NGO representatives and people from the study communities.

\section{Results}

\section{Perceptions vs meteorological records (category 1)}

Our focus groups and interviewees were asked to describe their perceptions of how the "weather" (see above) had changed, and timelines were constructed (e.g. Fig. 2). 
Communities' recollections of periods of drought and major storms (including hurricanes) in addition to the specific information provided could then be compared with meteorological records from the closest meteorological stations, annual reports from CONAGUA (since 2011) and nationally compiled estimates of 12-month SPI (Standard Precipitation Index).

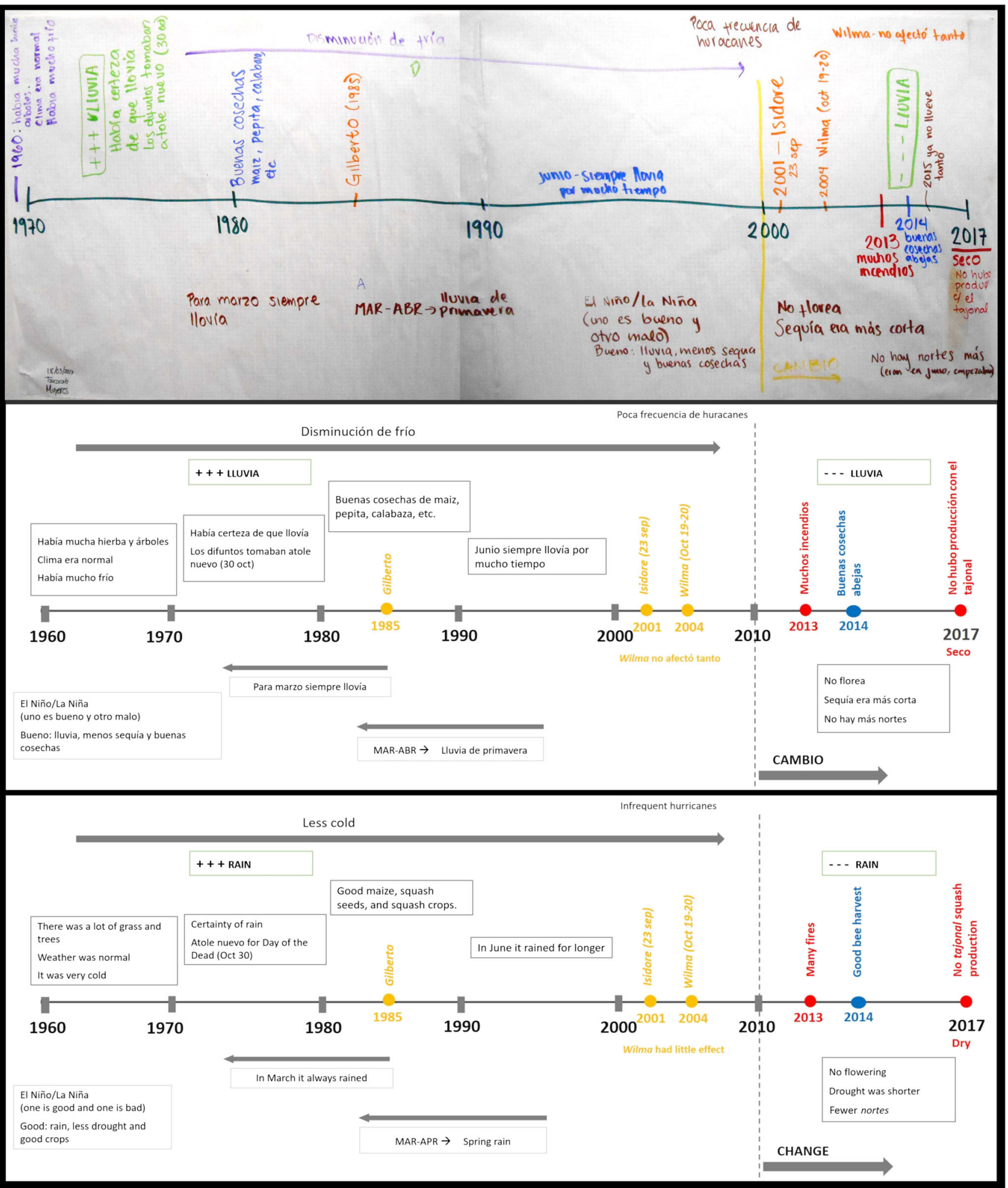

Fig. 2 Timeline from Tzucacab. Top panel, original timeline from workshop; middle panel, in Spanish; bottom panel, in English. Hurricane names in orange, droughts/fires in red and good harvests in blue 
Most of the fieldwork for this study took place in the early 2017 after a long period of drought (> 6 months) across much of southern Mexico in 2016 and extreme drought in early 2017 (CONAGUA 2016, 2017). Many participants saw this drought as being particularly severe, probably reflecting its immediacy, but also the occurrence of unusual events (such as the desiccation of the normally perennially wet aguada on the Hobonil ranch). By the end of 2017, total annual precipitation in QR and YUC was average and CAM above average. The years 2016 and 2017 also both recorded successive record high temperatures nationally, with much of the YP showing positive anomalies. This context probably affected respondents' perceptions of weather, with many people making comparisons against the 2016-2017 situation. Drought conditions were reported in all three communities. In San Felipe, it was compared with 2008 and 2010, but neither of these years appears in the top 10 driest years based on the meteorological site records (Online Resource 7). It seems likely that people were thinking of 2009, which SPI maps show to have been extremely dry across the YP. All three meteorological stations near Tzucacab place 2009-2010 in the top four driest years, and some stations near Calakmul also show that 2009 was very dry (Online Resource 7).

Changes in the timing of rainfall through the year were noted; respondents from Calakmul suggested that there was less rain early in the season "now in June it doesn't rain, there is a lot of drought, it's like a movement of the earth how this has changed, this is what I have noticed" (March 6, 2017). Meteorological records from Calakmul and Tzucucab do show a significant drying trend in the spring months (FebruaryApril), with all stations analysed showing a drying trend in the dry season (November-April). Participants from Tzucacab and Calakmul also referred to changes in the canicula (midsummer drought, mainly late July and August), which is not usually that pronounced in the YP. Meteorological records confirm that July has become significantly drier around these locations. A number of respondents even noted changes within a day "now it rains less in the morning ........in the past it rained in the morning as well, in the morning and in the evening, now it only rains in the evening and hardly at all in the morning" (March 14, 2017). Although a full analysis of the meteorological station data revealed no consistent trends in total annual precipitation or total wet season precipitation, it was clear that perceptions of dry season and early wet season changes were broadly consistent with observations.

The impact of hurricanes, both positive and negative, was reported by community members. The significance of the rain associated with hurricane Roxanne (1995) was reported at Calakmul (where it brought an end to a period of drought), while the impacts of Gilbert (1988) and Isidore (2002) were reported in the timelines at San Felipe and Tzucacab (Fig. 2 and see below). Whether hurricanes have an impact on total annual rainfall is highly variable, often depending more on the speed of transit of the cyclone (slow bringing more rain) than its intensity. In contrast, storm intensity is directly related to wind speed and hence the likelihood of damage to structures, crops and natural vegetation.

Participants from all communities referred to traditional practices of weather forecasting and local ecological knowledge (observations of plants and animals) to track wet and dry years and the arrival of rain. A respondent at Hobonil noted that "when the ants are full of eggs, then rain is close, the same with tarantulas when they cover their holes it is going to rain and if not, then that's because there is a long drought" (March 18, 2017) and "when chachalacas [a chicken type bird] are singing this means that you will see rain" (March 18, 2017). Traditional weather forecasts are closely bound up with the concept of cabañuelas, where the weather during January provides a guide to the weather through the rest of the year. Community members from both Tzucacab and Calakmul referred to the traditional use of the cabañuelas as a guide of both how much land to plant and when. In San Felipe, something similar was done based on placing grains of salt (one for each month) into a box between 1 st and 20th of January. Grains that remained intact signified drought. In Calakmul, the use of observations of the new moon to predict whether rain or drought was coming was also noted. Participants in Tzucacab described the ceremony of huajicol (making offerings to Maya deities) to ensure good rainfall and give thanks for a good harvest. In San Felipe, ranchers sometimes carried out a ceremony called Ch'a'Cháak, making offerings to the Maya rain god Chac, to ask for rain. This usually took place in June and July. It was reported, however, that the younger members of the communities had little interest or belief in these traditional practices and that in recent years, the forecasts from cabañuelas had become less reliable. One participant noted "in the past, yes, the cabañuelas worked, but not for about the last 30 years, the weather is changing and we are changing our planting times" (March 9, 2017). This theme of a changing climate and the need to adapt practices accordingly was picked up in all communities and is discussed further below.

\section{Lived situation and climate impacts (categories 2 and 3)}

The impacts of drought were widely reported across all three communities, although only those at Calakmul, which lack piped water (see above) referred to direct shortages of water for human use. In all cases, droughts have led to a reduction in the area under milpa, sometimes because the reduced yields rendered this form of cultivation less worthwhile. The reduction in milpa was particularly clear in Tzucacab and Calakmul for the period since 2000. At Calakmul, direct damage to crops due to high temperatures was also reported. Around Tzucacab, where there is more irrigation than at the other two locations, droughts resulted in a shortage of irrigation 
water, and it was felt that even when irrigation water was available, its poor quality (higher salinity) resulted in reduced crop yields. Here, losses were reported for "garden" crops including chilli, coriander and radishes, as well as the milpa staples. Reduced maize yields meant that people had to buy maize flour (maseca) to make common dishes such as pozole. At Calakmul and Tzucacab, loss of honey production was referred to specifically, as dry conditions reduced flowering of key species that provide nectar. One respondent noted that 'It's not the same....before I had my bees ... and in February I cleaned my hives, collected the honey, but now there is no rain and there are no flowers, last February there were almost no flowers and I could not collect honey" (March 4, 2017). In all cases, droughts were associated with greater losses to pests and wild animals. At Calakmul, woodland animals were attracted to the solares (house garden plots) and damaged maize plants and at Tzucacab, increases in pests including rats, racoons and parrots were noted, with some small-scale producers loosing up to $50 \%$ of their crop this way. Ranchers around San Felipe reported large numbers of pheasants, presumably attracted to water provided to livestock, although they did provide an additional source of food. Reduced grazing was noted in all locations and at Tzucacab, drought was also associated with reduced fertility in cattle. At Calakmul, a drought reported to have occurred in 2002 (although the data suggest that this might have been 2003, see Online Resource 7) resulted in the deaths of around 100 cattle and abandonment of Nuevo Becal because of lack of water. At Calakmul, it was noted that the changing pattern of precipitation through the year meant that the traditional system of double cropping (two crops per year) was no longer sustainable. Increasing variability in the onset of the rainy season, particularly years in which it started late (late July or August), was reported to have adverse impacts on maize production. For ranchers around San Felipe, the key impacts of drought were a loss of grazing, the drying of water holes and natural wells (rejolladas) and the spread of prickly pear (Tuna silvestre). Two activities that benefited from drought were salt production along the north coast and timber extraction around Calakmul (because tracks remained passable even in the wet season).

The impacts of hurricanes and other tropical storms were more variable. Respondents from Calakmul noted that they had mixed effects, bringing vital rain, but also causing flooding. A respondent noted that "Roxana was big, the water was $3 \mathrm{~m}$ deep in my house and we went to the school, the houses filled with water" (March 10, 2017). Extremely intense rainfall and high winds would both damage standing crops. Around Tzucacab, the emphasis was more on damage due to flooding. The impact of hurricane Gilbert (1988) (Fig. 2) was such that "the soldiers brought food and gave us help to keep going when the cyclone was fierce, like Isidore" (March 18, 2017). It did so much damage that some people reduced the area of maize they cultivated to avoid similar losses in future, one respondent from 15 ha in the 1980 s to 0.5 ha today. Hurricane Isidore in 2002 left several communities in the municipality of Tzucacab under water for more than a month (Güemez and Quintal 2003). In the same area, hurricane Dean (2007) apparently left land near Tekax under water for 4 months. In the coastal community, hurricanes have a very direct impact on fishermen who cannot go out when major storms occur. It was also reported that the salt water brought inland with hurricanes, specifically Isidore (2002) and Dean (2007), had led to both short- and long-term issues with soil salinity, although saline soils are naturally quite widespread (Online Resource 5). On a smaller scale, respondents at San Felipe reported on the impacts of winter frontal systems associated with nortes. These also restrict the activity of fishermen, but are seen as positive by ranchers as the rain they bring improves grazing and fills water holes.

\section{Forms of adaptation, support and resilience (category 4, 5 and 6)}

Diversification of livelihoods has been a key part of adaptation across all groups, in all communities, whether through changes to traditional cultivation methods, broadening the range of economic activities or even dietary change. Here, we describe some of the changes that have taken place in order to improve the resilience of individuals and communities. Given the pronounced direct impact of water shortages in Calakmul, a major change has been the installation of a wide range of water storage devices, even though the quality of water from some of these was poor. People are also buying water, brought in by tanker. This was also the community where there was most direct evidence of out migration and reliance of remittances from family in the USA, or within Mexico. In coastal San Felipe, fisherwomen, organised in cooperatives, have started fishing for different species such as cacerolita de mar (Limulus polyphemus) and cangrejo maxquil (Liberia dubia) as octopus bait (used by male fishermen) or as bait for their own fisheries. This is apparently because of the relatively high economic value of the cangrejo (worth about $50 \%$ of the octopus itself) (Soares et al., 2014). There has also been a move towards a mix of fishing and ranching, with cattle ranching providing an alternative source of income during the closed season and when weather conditions are unsuitable for fishing. During the lucrative sea cucumber (mainly Holothuria and Isostichopus spp.) season (see above), some ranch workers work as fishermen. At Tzucacab, there was evidence of the children of ejidatarios abandoning milpa cultivation completely for other activities. At Calakmul, people were planting reduced areas of maize and diversifying the range of crops planted and their range of off-farm activities. There were also changes in cultivation practices, with a shift to crops with a shorter growing cycle and a change in the timing of cropping towards the late summer when rainfall was more reliable. There were reports that maize shortages led to shifts in diet away from the traditional tortillas and making tamales out of ingredients bought at 
the local shop. A similar need to change the timing of production was reported at Tzucacab, where one respondent noted that "nature is changing so that we cannot cultivate as we used to, we need to observe nature again, move our crops and develop a new calendar" (March 14, 2017). A change to maize varieties with a shorter growing season, such as Nal T'eel or Elotillo, that were less likely to be affected by drought, was also described. Some farmers were cultivating achiote trees (Bixa orellana) for their edible fruit. The more widespread use of trees for medicinal purposes and to try to support honey production and pastoral activities as a source of alternative food supplies was reported from Calakmul and Tzucacab. The adoption of silvo-pastoral methods was particularly evident at the Hobonil ranch where this approach is seen as a key means of improving animal health and drought resilience. The potential of forests and forest management to support sustainable development was also noted by Schneider and Haller (2017). Ranchers at both San Felipe and Hobonil reported the use of non-traditional types of cattle feed to reduce reliance on poor quality pasture, including a mix of chicken droppings and bedding at San Felipe (although not recommended by Sagarpa) and silage at Hobonil.

A range of government support schemes are available to reduce the vulnerability of small-scale farmers and fishermen to climate change and extreme events, including the provision of weather forecasts to farmers associations and smallholders to help them plan the next cropping cycle (INIFAP and Rural Development Agencies); the promotion of irrigation systems through a $50-50 \%$ investment with the producer (CONAGUA); the FONDEN catastrophe bonds; and the CADENA index-based weather insurance scheme (see above). San Felipe has received funding through a wide range of schemes (national and international) aimed at supporting fisheries, tourism and the natural environment (Gavaldón Hoshiko 2004) as well as post-disaster support through Siniestra (Online Resource 5). As mentioned above, the PET and Peso $\times$ Peso schemes are important here. Some people also access the PROCAMPO scheme (see above and Online Resource 2), although a number of respondents noted that fishermen accessed these funds, but did not use them in the way that was intended. It was also noted that government support schemes were only available to private land owners or ejidatarios. In the area around Tzucacab, government support (including funding to bring in electricity supplies) through SAGARPA (now SADER) for wells and irrigation schemes has been important over several decades. In 2017, there were 8 SAGARPA programmes active in the area, covering farming, ranching and support for smallholders. These programmes included some funding through CADENA. For the ejidos of Calakmul, government support schemes, especially Prospera, have been particularly important, providing money to buy basic foodstuffs. However, recent droughts have meant that the insurers have now refused to compensate farmers for losses to their maize crops, whilst continuing to provide some limited payment for losses of other crops.

In spite of this range of interventions, actions seem to be isolated rather than integrated, sometimes contradictory, failing to meet the objectives set out in the federal PECC. According to the Head of Planning of SEMARNAT and the Head of the Mitigation and Adaptation Department of the Secretariat of Environment (both QR), problems with the programmes to tackle climate change are the lack of continuity and the absence of monitoring and evaluation of the proposed actions. This often occurs due to internal governmental changes, particularly changes in administrations at the municipal level, which occur every 3 years (rather than 6 years nationally). At our project workshop, it was also made clear that federal support schemes were often felt to be unsuitable for the YP as they were not orientated towards subsistence producers and there were complaints that rules, about things such as water abstraction, were not being applied evenly. In practical terms, the difficulties of dealing with online application systems for government grants were also raised.

\section{Discussion and conclusions}

The study of community experiences and perceptions is an essential ingredient of knowledge about how to face climate change, because it grounds scientific conceptions in peoples' everyday lived experience and well-being (Hulme 2009). Climate change is not only about scientific facts but also exists as a "popular" idea, imagined and shaped by human experiences and culture, particularly among small-scale fishing and farming communities who depend heavily on the climate for their subsistence/survival. Here, we have drawn out the impacts, perceptions and adaptations to extreme weather of three such communities across the Yucatan Peninsula, exploring this in relation to ideas of resilience, specifically livelihood resilience (Tanner et al. 2015), but our findings have wider significance, as set out below. Our main concern is how people are making sense of climate change/extreme weather events within their lives and how they are able to cope/adapt to it whilst maintaining (and ideally improving) their standards of living. Changes in el tiempo (weather) were generally recognised across the communities, if not expressed as "climate change". In contrast to a range of African studies (e.g. Eguanvoen et al. 2013), we found little evidence for cultural attributions of blame related to climate change. There were some differences between farmers' perceptions of change and that indicated by local instrumental records, for example, some of our informants expressed the belief that the weather was getting drier, a view not supported by the data. Overall, however, there was good correspondence between local perceptions of both trends and events and direct records. Our respondents' perceptions of changes in the timing of precipitation in particular had important implications for their farming activities. Both these findings are consistent with an Ethiopian study reported 
by Yayeh Ayal and Leal Filho (2017) and a meta-analysis carried out by Savo et al. (2016). They also reinforce the importance of climate as part of the lived environment (Taylor 2014). The changes in the climate were also affecting the acceptance and application of traditional weather lore and cultural practices (see Sánchez Cortés and Lozos Chavera, 2011 for another example in Mexico), as also reported for Lesotho (Pepin, 1996) and Malawi (Kalanda-Joshua et al. 2011). Our project workshop participants, academics, farmers and fishermen, emphasised the variable nature of climatic change and its impacts, spatially, temporally and between different members of individual communities, even those that might be perceived externally to be relatively homogeneous (e.g. different types of fishermen in San Felipe). It was evident that although people were aware of climatic change, it was not always a top priority given the other pressures of daily life, although our more recent work at Calakmul indicates that this may have changed over the last 2 years.

Droughts were commonly reported as leading to a reduction in the area under milpa. Nevertheless, this decrease in area under milpa is a response to the combined impacts of both climatic and non-climatic drivers, such as changes in agricultural policy, subsidies and crop prices (Appendini 2014). The importance of these other drivers (the issue of "double exposure") has been highlighted in other studies within Mexico (Eakin 2000; Saldaña Zorrilla 2008) and elsewhere (e.g. Mertz et al. 2009 in Senegal, Taylor 2013 in India). In contrast, the impacts of hurricanes and tropical storms were more variable, having both positive and negative elements. In San Felipe, fishermen were negatively affected by both major storms and smaller-scale frontal systems, while the extra rain brought by these systems was seen as positive by ranchers. The direct threat to coastal communities from hurricanes has previously been noted by Soares et al. (2014).

Diversification has been a key part of adaptation to an increasingly variable climate, as well as to an economic context which is hostile to small scale, subsistence, agriculture and fishing. The importance of diversification across this area was also noted by Audefroy and Cabrera Sánchez (2017). As previously reported by Perea Blázquez (2011) and Mardero et al. (2015), the changing pattern of precipitation within the wet season is causing farmers to adjust their agricultural calendar. Traditional double cropping is no longer sustainable, further threatening rural livelihoods and traditional farming systems. In some cases however (e.g. Calakmul), off farm diversification and state subsidies have actually allowed households to maintain their milpas for subsistence and cultural reproduction (Radel et al.; 2010; Schmook et al. 2013). Although diversification may seem to be key for successful adaptation, too much diversification may make livelihoods even more precarious (Christman et al. 2015). Diversification by smallholders has a long history of study and is itself multifaceted, with a large-scale study by Chen et al. (2018) indicating major variability between global regions and that what they describe as adaptation by diversification is largely determined by local scale factors. Our research has also shown that the generalised decrease in maize production drives families to rely increasingly on purchased food, a change that may well make people more vulnerable in the long term. Olvera et al. (2017) show that this trend is not only caused by decreased production, but is also reinforced by state subsidies like Prospera, which by providing cash to mothers increases the intake of highly calorific industrialised foods, rich in fats, sugars and salt.

As reported by Soares et al. (2014), it is evident that local adaptation strategies are much more specific than those set out in state level action plans (PEACCs, see above). Local people have a clear understanding of their own capacities and capabilities, embedded within local perceptions and understandings of climate change, but these can be quite variable between different parts of those communities. In San Felipe, a distinctive feature has been the development of strong community participation and organisation to address and adapt to extreme events (see also Soares et al. 2014), driven initially by the town's vulnerability to hurricanes. This community showed a move to livelihoods that more often combine fishing, farming and ranching, with a notable reduction in reliance on fishing alone. Discussions in our project workshop in Merida suggested future vulnerability for both fishing and ranching; local participants seemed to believe that neither activity were economically viable in the long term. Increasing tourist development along this part of the Yucatan coast is also having an impact. At Tzucacab, greater exploitation of forest resources was a notable feature. As described above, this exploitation took a range of forms. Here, the feeling was that farmers had been more badly affected by droughts than ranchers. Calakmul, the community most vulnerable to water shortages because of a lack of piped water for domestic use and irrigation, showed evidence of families increasing their water storage capability and an overall decline in the area under milpa. Delayed planting, to exploit later rains, was a specific adaptation mentioned here. This was also the community where remittances from family members based in the USA were particularly important. These communities displayed different levels of livelihood resilience, with the Calakmul ejidos being the most vulnerable. In the terminology of Eakin et al. (2014), Calakmul seems to fall into the very vulnerable "Poverty Trap" category.

Besides the adaptation strategies at household and community level, federal and state level actions have been introduced to address the adverse effects of climate change and try to reduce vulnerability in relation to society, infrastructure and ecosystems. The efficacy of these schemes was questioned by both state level officials and local people because of a lack of continuity, consistency and apparent relevance to individual livelihoods and contexts. Audefroy and Cabrera Sánchez (2017) for example have described the impacts of government funding schemes to encourage the replacement of traditional wooden houses with concrete block 
houses in the area around San Felipe, even though the concrete is quickly damaged by the high salinity and new buildings are out of keeping with the traditional style of the area (increasingly important for the growing tourist industry).

The most recent population projections for Mexico (CONAPO 2018) indicate that the states of the YP are likely to see some of highest levels of population growth in Mexico through to 2050 (by $>40 \%$ for both QR and CAM). Combined with projections of quite large decreases in the all-important summer rainfall (estimated by Colorado-Ruiz et al. 2018 to be around $13 \%$ less by the end of the century), the pressures on communities, particularly those reliant on agriculture, are likely to increase. Those dependent on small scale or subsistence production, without access to irrigation, will probably be worst affected. Our study has recorded some of the adaptations already made by communities to cope with what is perceived to be an increasingly variable climate, in some cases resulting in quite profound changes in livelihood strategies. In the YP, as elsewhere in the Global South (Pischke et al. 2018), communities are struggling to adapt to multiple stressors, and challenging economic and political contexts are likely to continue.

As described above, to date, federal and state actions in Mexico in relation to climate change have focused on mitigation rather than adaptation. Following on from the accords reached at COP21 in Paris in 2015 (Article 7), recognising the importance and urgency of implementing adaptation measures (particularly in the most vulnerable countries), this has started to change. Mexico is now committed to the development of a National Adaptation Policy (Politica Nacional de Adaptación) for implementation between 2020 and 2030 (INECC 2018). The collation of knowledge collected at local level, of the sort presented in this study, should inform the development of a meaningful dialogue between local, particularly rural, communities and policy makers and administrators to help this policy to generate appropriate adaptation strategies. The need to gather local-scale insights and recognise local environmental knowledge if adaptation strategies are to be successful has been identified in studies elsewhere (Alexander et al. 2011; Savo et al. 2016; Scoones 2016). Dilling et al. (2019), in a critique of the application of the Paris agreement to adopt and review adaptation, also emphasise the need to involve local people in the process of assessing whether adaptation has been successful and to take a long-term approach. The adoption of the approach set out in this paper could provide a useful, generally applicable template to increase adaptive capacity, to reduce vulnerability to extreme weather and ensure resilient livelihoods and communities over the long term.

Acknowledgements We would like to thank all the members of the communities we worked with for their support, time and enthusiasm. Dr. Francisco Bautista, Centro de Investigaciones en Geografia Ambiental, UNAM, was also a member of our team. We would also like to thank Santos Hoil (Rancho Hobonil) and Vanessa Escalante for the help with the workshop. Two reviewers provided helpful comments which have improved this paper.
Funding information This work was supported by the Natural Environment Research Council (NERC) GCRF grant number NE/ P015379/1.

Open Access This article is licensed under a Creative Commons Attribution 4.0 International License, which permits use, sharing, adaptation, distribution and reproduction in any medium or format, as long as you give appropriate credit to the original author(s) and the source, provide a link to the Creative Commons licence, and indicate if changes were made. The images or other third party material in this article are included in the article's Creative Commons licence, unless indicated otherwise in a credit line to the material. If material is not included in the article's Creative Commons licence and your intended use is not permitted by statutory regulation or exceeds the permitted use, you will need to obtain permission directly from the copyright holder. To view a copy of this licence, visit http://creativecommons.org/licenses/by/4.0/.

\section{References}

Adger WN (2000) Social and ecological resilience: are they related? Prog Hum Geog 24:347-364. https://doi.org/10.1191/030913200701540465

Adger WN, Barnett J, Brown K, Marshall N, O’Brien K (2013) Cultural dimensions of climate change impacts and adaptation. Nat Clim Chang 3:112-117. https://doi.org/10.1038/nclimate1666

Alexander C, Bynum N, Johnson E, King U, Mustonen T, Neofotis P, Oettle N, Rosenzweig C, Sakakibara C, Shadrin V, Vicarelli M, Waterhouse J, Weeks B (2011) Linking indigenous and scientific knowledge of climate change. Bioscience 61:477-484. https://doi. org/10.1525/bio.2011.61.6.10

Appendini K, García Barrios R, de la Tejera B (2003) Seguridad alimentaria y "calidad" de los alimentos: ¿una estrategia campesina? Revista Europea de Estudios Latinoamericanos y del Caribe 75:6583. https://doi.org/10.18352/erlacs. 9694

Appendini K (2014) Reconstructing the maize market in rural Mexico. J Agrar Change 14:1-25. https://doi.org/10.1111/joac.12013

Arora-Jonsson S (2011) Virtue and vulnerability: discourses on women, gender and climate change. Global Environ Chang 21:744-751. https://doi.org/10.1016/j.gloenvcha.2011.01.005

Audefroy JF (2015) Potential effects of climate change on the habitat in Mexico. Disaster Prev Manag 24:249-262. https://doi.org/10.1108/ DPM-08-2014-0166

Audefroy JF, Cabrera Sánchez BN (2017) Integrating local knowledge for climate change adaptation in Yucatan, Mexico. Int J Sustain Built Environ 6:228-237. https://doi.org/10.1016/j.ijsbe.2017.03.007

Blunden J, Arndt DS Eds. (2017) State of the climate in 2016. Bull Amer Meteor Soc 98:Si-S277. https://doi.org/10.1175/ 2017BAMSStateoftheClimate. 1

Blunden J, Arndt DS Eds. (2018) State of the climate in 2017. Bull Amer Meteor Soc 99:Si-S332. https://doi.org/10.1175/ 2018BAMSStateoftheClimate. 1

Borja-Vega C, de la Fuente A (2013) Municipal vulnerability to climate change and climate-related events in Mexico municipal vulnerability to climate change and climate-related events in Mexico. Policy research working paper 6417, World Bank

Brown K (2014) Global environmental change I: a social turn for resilience? Prog Hum Geog 38:107-117. https://doi.org/10.1177/ 0309132513498837

Cannon T, Muller-Mahn D (2010) Vulnerability, resilience and development discourses in context of climate change. Nat Hazards 55:621635. https://doi.org/10.1007/s11069-010-9499-4

Chen M, Wichmann B, Luckert M, Winowiescki L, Förch W, Läderach P (2018) Diversification and intensification of agricultural adaptation 
from global to local scales. PLoS One 13:e0196392. https://doi.org/ 10.1371/journal.pone.0196392

Christensen JH, Krishna Kumar H, Aldrian E, An S-I, IAF C, de Castro M, Dong W, Goswami P, Hall A, Kanyanga JK, Kitoh A, Kossin J, Lau NC, Renwick J, Stephenson DB, Xie S-P, Zhou T (2013) Climate phenomena and their relevance for future regional climate change. In: Stocker TF, Qin D, Plattner G-K, Tignor M, Allen SK, Boschung J, Nauels A, Xia Y, Bex V, Midgley PM (eds) Climate change 2013: the physical science basis. Contribution of Working Group I to the Fifth Assessment Report of the Intergovernmental Panel on Climate Change. Cambridge University Press, Cambridge, United Kingdom and New York

Christman Z, Pearsall H, Schmook B, Mardero S (2015) Diversification and adaptive capacity across scales in an emerging post-frontier landscape of the Usumacinta Valley, Chiapas. Mexico Int For Rev 17:11-123. https://doi.org/10.1505/146554815814669016

Clayton S, Devine-Wright P, Stern PC, Whitmarsh L, Carrico A, Steg L, Swim J, Bonnes M (2015) Psychological research and global climate change. Nat Clim Chang 5:640-646. https://doi.org/10.1038/ NCLIMATE2622

Colorado-Ruiz G, Cavazos T, Salinas JA, De Grau P, Ayala R (2018) Climate change projections from Coupled Model Intercomparison Project phase 5 multi-model weighted ensembles for Mexico, the North American monsoon, and the mid-summer drought region. Int J Climatol 38:5699-5716. https://doi.org/10.1002/joc.5773

CONAGUA (2016) Reporte del Clima en México. CONAGUA, Mexico https://smn.cna.gob.mx/es/climatologia/diagnostico-climatico/ reporte-del-clima-en-mexico

CONAGUA (2017) Reporte del Clima en México. CONAGUA, Mexico https://smn.cna.gob.mx/es/climatologia/diagnostico-climatico/ reporte-del-clima-en-mexico

CONAPO (2016) Índice de marginación por entidad federativa y municipio 2015. Consejo Nacional de Población. https://www.gob. $\mathrm{mx} /$ conapo/documentos/indice-de-marginacion-por-entidadfederativa-y-municipio-2015

CONAPO, 2018 Proyecciones de la Población de México y de las Entidades Federativas 2016-2050. Consejo Nacional de Población. https://www.gob.mx/conapo/acciones-y-programas/conciliaciondemografica-de-mexico-1950-2015-y-proyecciones-de-la-poblacionde-mexico-y-de-las-entidades-federativas-2016-2050

de la Fuente A, Olivera Villaroel M (2013) The poverty impact of climate change in Mexico. In: Policy research working paper, vol 6461. World Bank

de Vet E (2013) Exploring weather-related experiences and practices: examining methodological approaches. Area 45:198-206. https:// doi.org/10.1111/area.12019

Diario Oficial de la Federación (2014) Programa Especial de Cambio Climático 20142018 (PECC). https://www.gob.mx/cms/uploads/ attachment/file/314952/Logros PECC 2016.pdf

Dilling L, Prakash A, Zommers Z, Ahmad F, Singh N, de Wit S, Nalau J, Daly M, Bowman K (2019) Is adaptation success a flawed concept? Nat Clim Chang 9:572-574. https://doi.org/10.1038/s41558-019-0539-0

Dodman D, Mitlin D (2013) Challenges for community-based adaptation: discerning the potential for transformation. J Int Dev 25:640-659. https://doi.org/10.1002/jid.1772

Douglas PMJ, Pagania M, Canuto MA, Brenner M, Hodell DA, Eglinton TI, Curtis JH (2015) Drought, agricultural adaptation, and sociopolitical collapse in the Maya Lowlands. Proc Nat Acad Sciences 112:5607-5612. https://doi.org/10.1073/pnas.1419133112

Doulton H, Brown K (2009) Ten years to prevent a catastrophe? Discourses of climate change and international development in the UK press. Global Environ Chang 19:191-202. https://doi.org/10. 1016/j.gloenvcha.2008.10.004

Duxfield F (2007) The twin crises of climate change. Just Change: Critical Thinking on Global Issues: Special Issue Going Under: Te korokoro o te Parata 10: 6-10
Eakin H (2000) Smallholder maize production and climatic risk: a case study from Mexico. Climatic Change 45:19-36. https://doi.org/10. 1023/A:1005628631627

Eakin H (2005) Institutional change, climate risk, and rural vulnerability: cases from Central Mexico. World Dev 33:1923-1938. https://doi. org/10.1016/j.worlddev.2005.06.005

Eakin HC, Lemos MC, Nelson DR (2014) Differentiating capacities as a means to sustainable climate change adaptation. Global Environ Chang 27:1-8. https://doi.org/10.1016/j.gloenvcha.2014.04.013

Echánove F, Steffen C (2003) Coping with trade liberalization: the case of Mexican grain producers. Cult Agric 25:1-12. https://doi.org/10. 1525/cag.2003.25.2.1

Eguanvoen I, Schulz K, de Wit S, Weisser F. Müller-Mahn D (2013) Political dimensions of climate change adaption: conceptual reflections and African examples. ZEF working paper series, no. 120, University of Bonn, Center for Development Research (ZEF), Bohn. http://hdl.handle.net/10419/88332

Endfield GE, Morris C (2012) Cultural spaces of climate. Clim Chang 113:1-4. https://doi.org/10.1007/s10584-012-0416-6

Eriksen SH, Nightingale AJ, Eakin H (2015) Reframing adaptation: the political nature of climate change adaptation. Global Environ Chang 35:523-533. https://doi.org/10.1016/j.gloenvcha.2015.09.014

Gaillard JC (2010) Vulnerability, capacity and resilience: perspectives for climate and development policy. Int Dev 22:218-232. https://doi. org/10.1002/jid.1675

Gavaldón Hoshiko AC (2004) Género, pesquerías e instituciones: estudio de caso en un puerto de Yucatán. MSc thesis, CINVESTAV-Unidad Merida, Yucatan

García Acosta V (2002) Huracanes y/o desastres en Yucatán. Revista de la Universidad Autónoma de Yucatan 223:3-15

García de Fuentes A, Xool Koh M, Euán Ávila JI, Munguía Gil A, Cervera Montejano MD (2011) La costa de Yucatán en la perspectiva del desarrollo turístico. Colección Corredor Biológico Mesoamericano México Serie Conocimientos / Número 9:86 pp

García Gil G, Palacio Prieto JL, Ortiz Pérez MA (2002) Reconocimiento geomorfológico e hidrográfico de la Reserva de la Biosfera Calakmul, México. Investigaciones Geográficas, Boletin del Instituto de Geografia UNAM, 48: 7-23

Gobierno del Estado de Yucatán (2013a) Plan Estatal de Desarrollo 2012-2018. Gobierno del Estado de Yucatán. Merida, México http://www.yucatan. gob.mx/docs/transparencia/ped/2012_2018/PED_2012_2018.pdf

Gobierno del Estado de Yucatán (2013b) Atlas de Peligros por Fenómenos Naturales del Estado de Yucatán. http://www. proteccioncivil.gob.mx/work/models/ProteccionCivil/ swbcalendario ElementoSeccion/535/II INFORME EJECUTIVO_ATLAS_DE_PELIGROS_POR_FEN_MENOS NATURALES $\overline{-}$ DEL ESTTAD̄O DE YUCAT N.PDF

Gobierno del Estado de Yucatán (2014a) Programa Especial de Acción ante el Cambio Climático del Estado de Yucatán. http://www.ccpy. gob.mx/agenda-yucatan/programa-estatal-cambio-climatico.php

Gobierno del Estado de Yucatán (2014b) Annex 6. Analisis de la variabilidad climática e impactos socio-económicos de fenómenos hidrometeorológicos extremos en los sectores y sistemas de interés para el Estado. http://www.ccpy.gob.mx/pdf/agenda-yucatan/ documentos-estatal/anexos_peacc/anexo6.pdf

Gobierno del Estado de Yucatán (2014c) Annex 7. Análisis de la vulnerabilidad actual y futura ante el cambio climático. http:// www.ccpy.gob.mx/pdf/agenda-yucatan/documentos-estatal/ anexos_peacc/anexo7.pdf

Gravel N (2007) Mexican smallholders adrift: the urgent need for a new social contract in rural Mexico. J Lat Am Geog 6:77-98 Retrieved from http://www.jstor.org/stable/25765179

Guest G, Bunce A, Johnson L (2006) How many interviews are enough? An experiment with data saturation and variability. Field Method 18: 59-82. https://doi.org/10.1177/1525822X05279903 
Hackmann H, Moser SC, St. Clair AL (2014) The social heart of global environmental change. Nat Clim Chang 4:653-655. https://doi.org/ 10.1038 /nclimate 2320

Hoddinott J, Skoufias E, Washburn R (2000) The impact of PROGRESA on consumption: a final report. International Food Policy Research Institute, Washington, DC Retrieved from https://ageconsearch. umn.edu/record/16023/files/mi00ho02.pdf

Hollander JA (2004) The social contexts of focus groups. J Contemp Ethnogr 33:602-637. https://doi.org/10.1177/0891241604266988

Hulme M (2009) Why we disagree about climate change: understanding controversy, inaction and opportunity. Cambridge University Press, Cambridge

Ibarra-Manríquez G, Villaseñor JL, Durán R, Meave J (2002) Biogeographical analysis of the tree flora of the Yucatan Peninsula. J Biogeogr 29:17-29. https://doi.org/10.1046/j.13652699.2002.00648.x

INECC (2018) Diseño e implementación de medidas de adaptación al cambio climático en México. Resumen Informativo, Ciudad de México http://encuentronacional.cambioclimatico.gob.mx/ Descargas/resumen/adaptacion.pdf

INEGI (2015) Anuario estadÍstico y geográfico de Campeche 2015. http://internet.contenidos.inegi.org.mx/contenidos/Productos/prod serv/contenidos/espanol/bvinegi/productos/nueva_estruc/anuarios 2015/702825077198.pdf

INEGI and Gobierno del Estado de Yucatán (2015) Anuario estadístico y geográfico de Yucatán 2015. https://www.inegi.org.mx/app/ biblioteca/ficha.html?upc=702825077235

INEGI Encuesta Intercensal (2016) Principales resultados de la Encuesta Intercensal 2015 Yucatan. http://internet.contenidos.inegi.org.mx/ contenidos/Productos/prod_serv/contenidos/espanol/bvinegi/ productos/nueva estruc/inter censal/estados2015/702825080051.pdf

INEGI and Gobierno del Estado de Yucatán (2017) Anuario estadístico y geográfico de Yucatán 2017. http://internet.contenidos.inegi.org. $\mathrm{mx} /$ contenidos/Productos/prod serv/contenidos/espanol/bvinegi/ productos/nueva_estruc/anuarios_2017/702825095116.pdf

INEGI and Gobierno del Estado de Campeche (2017) Anuario estadístico geográfico de Campeche:2017 https://www.datatur.sectur.gob.mx/ ITxEF_Docs/CAM_ANUARIO_PDF.pdf

IPCC (2014) Climate change 2014: impacts, adaptation, and vulnerability. Part B: regional aspects. Contribution of Working Group II to the Fifth Assessment Report of the Intergovernmental Panel on Climate Change. Barros VR, field CB, Dokken DJ, Mastrandrea MD, Mach KJ, Bilir TE, Chatterjee M, Ebi KL, Estrada YO, Genova RC, Girma B, Kissel ES, levy AN, MacCracken S, Mastrandrea PR, white LL (eds.). Cambridge University Press, Cambridge, United Kingdom and New York, pp. 688

Kalanda-Joshua M, Ngongondo C, Chipeta L, Mpembeka F (2011) Integrating indigenous knowledge with conventional science: enhancing localised climate and weather forecasts in Nessa, Mulanje, Malawi. Phys Chem Earth 36:996-1003. https://doi.org/10.1016/j. pce.2011.08.001

Márdero S, Nickl E, Schmook B, Schneider L, Rogan J, Christman Z, Lawrence D (2012) Sequías en el sur de la península de Yucatán: análysis de la variabilidad anual y estacional de la precipitación. Invest Geográf 78:19-33 http://www.scielo.org.mx/scielo.php? script=sci_arttext\&pid=S0188-46112012000200003

Mardero S, Schmook B, Radel C, Christman Z, Lawrence D, Millones M, Nickl E, Rogan J, Schneider L (2015) Smallholders' adaptations to droughts and climatic variability in southeastern Mexico. Env Hazards 14:271-288. https://doi.org/10.1080/17477891.2015.1058741

Mardero S, Schmook B, López-Martínez JO, Cicero L, Radel C, Christman Z (2018) The uneven influence of climate trends and agricultural policies on maize production in the Yucatan Peninsula, Mexico. Land 7:80. https://doi.org/10.3390/land7030080

Martínez Romero E (2010) Factores de impacto directos e indirectos que determinaron el proceso complejo de la deforestación a nivel ejidal, en la región de Calakmul, Campeche, durante el periodo 1976-2008. Doctorado de Investigación en Ciencia Sociales con Mención en Sociología; FLACSO México. México. 296 p

Mendoza B, García-Acosta V, Velasco V, Jáuregui E, Díaz-Sandova R (2007) Frequency and duration of historical droughts from the 16th to the 19th centuries in the Mexican Maya lands, Yucatan Peninsula. Clim Chang 83:151-168. https://doi.org/10.1007/s10584-006-9232-1

Mertz O, Mbow C, Reenberg A, Diouf A (2009) Farmers' perceptions of climate change and agricultural adaptation strategies in rural Sahel. Environ Manag 43:804-816. https://doi.org/10.1007/s00267-0089197-0

Mitchell T, Harris K (2012) Resilience: a risk management approach. ODI Background Note, www.odi.org.uk

Monitor de Sequía en Mexico https:/smn.cna.gob.mx/es/climatologia/ monitor-de-sequia/monitor-de-sequia-en-mexico and SPI (Standard Precipitation Index) https://smn.conagua.gob.mx/es/climatologia/ monitor-de-sequia/spi

Navarro-Martínez A, Durán-García R, Méndez-González M (2012) El impacto del huracán Dean sobre la estructura y composición arbórea de un bosque manejado en Quintana Roo, México. Madera Bosques 18:57-76 Available from http://www.scielo.org. $\mathrm{mx} / \mathrm{scielo} . \mathrm{php}$ ? script=sci arttext\&pid=S $1405-$ $04712012000100005 \& \operatorname{lng}=\mathrm{es} \& \mathrm{nrm}=\overline{\mathrm{iso}}$

Noy C (2008) Sampling knowledge: the hermeneutics of snowball sampling in qualitative research. Int J Soc Res Method 11:327-344. https://doi.org/10.1080/13645570701401305

O'Brien KL, Leichenko RM (2000) Double exposure: assessing the impacts of climate change within the context of economic globalization. Global Environ Chang 10:221-232. https://doi.org/10.1016/ S0959-3780(00)00021-2

Olvera B, Schmook B, Radel C, Nazar Beutelspacher DA (2017) Efectos adversos de los programas de apoyo alimentario en los hogares rurales de Calakmul, Campeche. Estud Soc 27:11-46 Available from: http://www.scielo.org.mx/scielo.php?script=sci_arttext\&pid= S0188-45572017000100011\&lng=es\&nrm=iso

Orellana R, Espadas C, Conde C, Gay C (2009) Atlas Escenarios de Cambio Climatico en la Peninsula de Yucatan. CICY Yucatan/ Centro de Ciencias de la Atmosfera UNAM, Mérida, Yucatán

Pepin N (1996) Indigenous knowledge concerning weather: the example of Lesotho. Weather 51:242-248. https://doi.org/10.1002/j.14778696.tb06222.x

Perea Blázquez AK (2011) Household level adaptation in the southern region of the Yucatan Peninsula. Tropical Resources: The Bulletin of TRI 30:53-60

Pischke EC, Mesa-Jurado MA, Eastmond A, Abrams J, Halvorsen KE (2018) Community perceptions of socioecological stressors and risk-reducing strategies in Tabasco, Mexico. J Environ Stud Sci 8: 441-451. https://doi.org/10.1007/s13412-018-0493-6

Posada Vanegas G, Vega Serratos BE, Silva Casarin R (eds) (2013) Peligros Naturales en el Estado de Campeche. Cuantificación y Protección Civil. Universidad Autónoma de Campeche, CENECAM-Gobierno del Estado de Campeche, CENAPRED. 202pp

Radel C, Schmook B, Chowdury RR (2010) Agricultural livelihood transition in the southern Yucatán región: diverging paths and their accompanying land changes. Reg Environ Chang 10:205-218. https://doi.org/10.1007/s10113-010-0113-9

Radel C, Schmook B, Haenn N, Green L (2017) The gender dynamics of conditional cash transfers and smallholder farming in Calakmul, Mexico. Women Stud Int Forum 65:17-27. https://doi.org/10. 1016/j.wsif.2016.06.004

Red de Género y Medio Ambiente (2010) Aportes de las experiencias comuntarias a las estrategias de adaptación al cambio climático en Mexico desde una perspectiva de género

Reenberg A, Vang Rasmussen L, Østergaard Nielsen J (2012) Causal relations and land use transformation in the Sahel: conceptual lenses 
for processes, temporal totality and inertia. Geogr Tidsskr-Den 112: 159-173. https://doi.org/10.1080/00167223.2012.741888

Rosales M, Rejon L (1983) Hacia una aproximación a las unidades de producción en la región sur de Yucatan. Rev Geog Agríc 5-6:171-189

Royal Society (2014) Resilience to extreme weather: executive summary. The Royal Society

Saldaña-Zorrilla SO (2008) Stakeholders' views in reducing rural vulnerability to natural disasters in Southern Mexico: Hazard exposure and coping and adaptive capacity. Global Environ Chang 18:583-597. https://doi.org/10.1016/j.gloenvcha.2008.09.004

Sánchez Cortés MS, Lozos Chavero E (2011) Indigenous perception of change in climate variability and its relationship with agriculture in a Zoque community of Chiapas. Clim Chang 107:363-389. https:// doi.org/10.1007/s10584-010-9972-9

Sánchez Triana E, Ruitenbeek J, Enruiqez S, Siegmann K, Pethick J, Scandizzo P, Larsen B, Strukova Golub, E (2016) Green and inclusive growth in the Yucatan Peninsula. The International Bank for Reconstruction and Development/The World Bank Report No: AUS6091

Savo V, Lepofsky D, Benner JP, Kohfeld KE, Bailey J, Lertzman K (2016) Observations of climate change among subsistenceoriented communities around the world. Nat Clim Chang 6:462473. https://doi.org/10.1038/nclimate2958

Schmook B, van Vliet N, Radel C, Manzon Che M, McCandless S (2013) Persistence of swidden cultivation in the face of globalization: a case study from communities in Calakmul, Mexico. Hum Ecol 41:93107. https://doi.org/10.1007/s10745-012-9557-5

Schmook B, Haenn N, Radel C, Navarro OS (2019) Empowering women? Conditional cash transfers in Mexico. In: Balen ME, Fotta M (eds) Money from the government in Latin America. Conditional Cash Transfer Programs and Rural Lives. Routledge, Oxford and New York, pp 97-113

Schneider L, Haller T (2017) A region under threat? Climate change impacts, institutional change and response of local communities in coastal Yucatan. In: Leal Filho W, Keenan J (eds) Climate change adaptation in North America. Springer, Cham, pp 161-175

Scoones I (2016) The politics of sustainability and development. Annu Rev Environ Resour 41:293-319. https://doi.org/10.1146/annurevenviron-110615-090039

Skoufias E (2005) PROGRESA and its impacts on the welfare of rural households in Mexico. Washington, DC: International Food Policy Research Institute (Research Report 139). Retrieved from https:// ageconsearch.umn.edu/bitstream/37891/2/rr139.pdf

Soares D, Murillo Licea D (2013) Gestión de riesgo de desastres, género y cambio climático. Percepciones sociales en Yucatán, México.
Cuad Desarro Rural 10:181-199 http://en.redalyc.org/articulo.oa? id $=11729823008$

Soares D, Munguía M-T, Millán G, Villareal J, Salazar H, Méndez G (2014) Vulnerabilidad y adaptación en Yucatán. Un acercamiento desde lo local y con enfoque de género. Instituto Mexicano de Tecnologia del Agua, Juitepec https://agua.org.mx/wp-content/ uploads/2015/06/vulnerabilidad-y-adaptacion-en-Yucatan.pdf

Tanner T, Lewis D, Wrathall D, Bronen R, Cradock-Henry N, Huq S, Lawless C, Nawrotzki R, Prasad V, Rahman Md A, Alaniz R, King K, McNamara K, Md N, Henly-Shepard S, Thomalla F (2015) Livelihood resilience in the face of climate change. Nat Clim Chang 1:23-26. https://doi.org/10.1038/nclimate2431

Taylor M (2013) Climate change, relational vulnerability and human security: rethinking sustainable adaptation in agrarian environments. Clim Dev 5:318-327. https://doi.org/10.1080/17565529.2013.830954

Taylor M (2014) The political ecology of climate change adaptation: livelihoods, agrarian change and the conflicts of development. Routledge Press

Turner BL II, Sabloff JA (2012) Classic Period collapse of the Central Maya Lowlands: insights about human-environment relationships and sustainability. P Natl Acad Scienci USA 109:13908-13914. https://doi.org/10.1073/pnas.1210106109

UADY (2003) Impacto del huracán Isidoro en Yucatán. Rev Universidad Autónoma de Yucatán 18 Special Issue. http://www.cirsociales. uady.mx/revUADY/ru224.php

Vester HF, Lawrence D, Eastman JR, Turner BL, Calmé S, Dickson R, Pozo C, Sangermano F (2007) Land change in the southern Yucatán and Calakmul biosphere reserve: effects on habitat and biodiversity. Ecol Appl 17:989-1003. https://doi.org/10.1890/05-1106

Weaver CP, Mooney S, Allen D, Beller-Simms N, Fish T, Grambsch AE, Hohenstein W, Jacobs K, Kenney MA, Lane MA, Langer L, Larson E, McGinnis DL, Moss RH, Nichols LG, Nierenberg C, Syller EA, Stern PC, Winthrop R (2014) From global change science to action with social sciences. Nat Clim Chang 4:656-659. https://doi.org/10. 1038/nclimate2319

Williams C, Fenton A, Huq S (2015) Knowledge and adaptive capacity. Nat Clim Chang 5:82-83. https://doi.org/10.1038/nclimate2476

Yayeh Ayal D, Leal Filho W (2017) Farmers' perceptions of climate variability and its adverse impacts on crop and livestock production in Ethiopia. J Arid Environ 140:20-28. https://doi.org/10.1016/j. jaridenv.2017.01.007

Publisher's note Springer Nature remains neutral with regard to jurisdictional claims in published maps and institutional affiliations.

\section{Affiliations}

\section{Sarah E. Metcalfe ${ }^{1}$ (D) $\cdot$ Birgit Schmook $^{2}$ (D) Doreen S. Boyd $^{1}$ (D) $\cdot$ Betsabe De la Barreda-Bautista $^{1}$ (D) $\cdot$ Georgina E. Endfield ${ }^{4}(1) \cdot$ Sofia Mardero $^{3} \cdot$ Maria Manzón Che $^{2} \cdot$ Roger Medina González $^{5} \cdot$ Maria Teresa Munguia Gil $^{6}$. Santana Navarro Olmedo ${ }^{2}$ (D) Alejandra Perea $^{6}$}

1 School of Geography, University of Nottingham, Nottingham NG7 2RD, UK

2 ECOSUR (El Colegio de la Frontera Sur), Av del Centenario Km 5.5, CP77014 Chetumal, Quintana Roo, Mexico

3 School of Geography and Sustainable Development, University of St. Andrews, St. Andrews KY16 9AL, UK
4 Department of History, Faculty of Humanities and Social Sciences, University of Liverpool, Liverpool L69 7WZ, UK

5 Campus de Ciencias Biólogicas y Agropecuarias, Facultad de Medicina Veterinaria y Zootecnica, Universidad Autonoma de Yucatán, Mérida, Mexico

6 Facultad de Ciencias Antropológicas, Universidad Autonoma de Yucatan, Merida, Mexico 